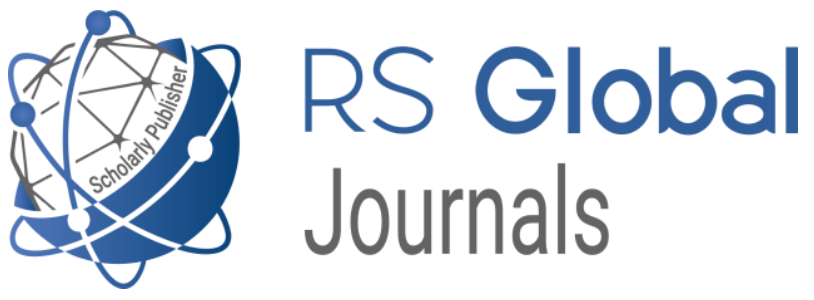

Scholarly Publisher

RS Global Sp. z O.O.

ISNI: 0000000484952390

Dolna 17, Warsaw, Poland 00-773

Tel: +48226022703

Email: editorial_office@rsglobal.pl

JOURNAL International Journal of Innovative Technologies in Social Science

p-ISSN

2544-9338

e-ISSN

2544-9435

PUBLISHER

RS Global Sp. z O.O., Poland

ARTICLE TITLE

АНАЛІЗ ЗВ'ЯЗКУ РІВНЯ СУБ'ЄКТИВНОГО

БЛАГОПОЛУЧЧЯ 3 АСПЕКТАМИ ЖИТТЯ УЧНІВ ПІДЛІТКОВОГО ТА РАННЬОГО ЮНАЦЬКОГО ВІКУ

$\operatorname{AUTHOR}(\mathbf{S})$

Халєєва Ганна Валеріївна

Khalyeyeva Ganna. (2021) Analysis of Connection of the Level of

ARTICLE INFO

Subjective Well-Being with Aspects of Life of Teenage and

Youth. International Journal of Innovative Technologies in Social

Science. 3(31). doi: 10.31435/rsglobal_ijitss/30092021/7674

DOI

https://doi.org/10.31435/rsglobal_ijitss/30092021/7674

RECEIVED

20 July 2021

ACCEPTED

06 September 2021

PUBLISHED

10 September 2021

LICENSE

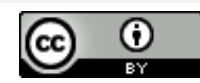

This work is licensed under a Creative Commons Attribution

4.0 International License.

(C) The author(s) 2021. This publication is an open access article. 


\title{
АНАЛІЗ ЗВ'ЯЗКУ РІВНЯ СУБ'СКТИВНОГО БЛАГОПОЛУЧЧЯ З АСПЕКТАМИ ЖИТТЯ УЧНІВ ПІДЛІТКОВОГО ТА РАННЬОГО ЮНАЦЬКОГО ВІКУ
}

\author{
Халєєва Ганна Валеріївна, \\ аспірант кафедри психології, Факультету філософії та суспільствознавства НПУ \\ імені М. П. Драгоманова, Київ, Україна, ORCID ID: https://orcid.org/0000-0002-8664-3650
}

DOI: https://doi.org/10.31435/rsglobal_ijitss/30092021/7674

\section{ARTICLE INFO}

Received 20 July 2021

Accepted 06 September 2021

Published 10 September 2021

\section{KEYWORDS}

adolescents, youths, subjective well-being, personality, aspects of life.

\begin{abstract}
The article gives a theoretical research analysis and demonstrates the link between the level of subjective well-being and such life aspects of personality as adaptation process to social environment, the effectiveness of interpersonal interaction, the ability to set life goals and realize motivation to goal achievement. Special attention is given to the lockdown conditions due to the Covid-19. The article provides results of intermediate research of the relationship between the level of subjective well-being and the following life aspects of adolescents and youth as the ability to self-regulating behavior, an adequate emotional assessment of demands and person's achievements, the ability to react congruently to changes in the environment prior to events and situations, the tendency to trust and goodwill, the ability of emotional awareness and adequate expression of feelings.
\end{abstract}

Citation: Khalyeyeva Ganna. (2021) Analysis of Connection of the Level of Subjective Well-Being with Aspects of Life of Teenage and Youth. International Journal of Innovative Technologies in Social Science. 3(31). doi: 10.31435/rsglobal_ijitss/30092021/7674

Copyright: (C) 2021 Khalyeyeva Ganna. This is an open-access article distributed under the terms of the Creative Commons Attribution License (CC BY). The use, distribution or reproduction in other forums is permitted, provided the original author(s) or licensor are credited and that the original publication in this journal is cited, in accordance with accepted academic practice. No use, distribution or reproduction is permitted which does not comply with these terms.

Вступ. В сучасний психології суб'єктивне благополуччя розглядається вітчизняними вченими як переживання особистості, та досліджується в контексті теорій саморегуляції, життедіяльності, спрямованих на зміну мети, мотивів, установок, світогляду Р. М. Шаміонов (Shamionov, 2004), Е. Е. Бочарова (Bocharova, 2012), Н. Р. Саліхова (Salikhova, 2015). Так, P. М. Шаміонов (Shamionov, 2004) відмічає посилення адаптивних можливостей особистості в сприйманні себе і свого життя при зростанні рівня суб'єктивного благополуччя. Є. Є. Бочарова (Bocharova, 2012) розглядає зв'язок рівня суб'єктивного благополуччя та процесу адаптації в соціальному середовищі, здатності ставити життєві цілі та зберігати мотивацію при їх досягненні. Н. Р. Саліхова (Salikhova, 2015), акцентує увагу на прагнення особистості до пошуку нових засобів втілення життєвих цілей, як зворотній зв'язок на досягнення чи не досягнення особистістю бажаного рівня суб'єктивного благополуччя Л. В. Куліков (Kulikov, 2004) підкреслює роль суб'єктивного благополуччя при успішній та ефективній міжособистісної взаємодії. Г. Л. Пучкова (Puchkova, 2003) в своїй роботі уточнює, що взаємовідношення між такими змінними, як суб'єктивне благополуччя та самооцінка $\epsilon$ двоспрямованим. I. С. Горбаль (Gorbal, 2016) звертає увагу на стимулюючу функцію суб'єктивного благополуччя, рівень якого обумовлює подальше зростання та розвиток особистості. Л. В. Романюк (Romanyuk, 2014) у своєму дослідженні виявила взаємозалежність цінностей особистості та її суб'єктивного благополуччя.

Зв'язок суб'єктивного благополуччя 3 аспектами життя як сукупності явищ, що супроводжують особистість в різні вікові періоди, досліджується зарубіжними вченими, які 
вивчають формування позитивного досвіду особистості в зв'язку 3 iï суб'єктивними судженнями про ефективність життя, самопочуття, ефективність соціальної взаємодії та адаптації (Diener, Oishi, \& Lucas, 2003), (Gasper, 2004), (Santrock, 2006).

Метою даної публікації є аналіз зв'язку рівня суб'єктивного благополуччя з аспектами життя учнів підліткового та раннього юнацького віку.

Матеріали і методи. В нашій роботі продемонстровані проміжні результати дослідження зв'язку рівня суб'єктивного благополуччя та функціонування особистості в період підліткового та раннього юнацького віку. В емпіричному дослідженні використано такий психодіагностичний інструментарій: Тест самовладання А. Золотарьова (Zolotareva, 2018), Методики дослідження рівня зазіхань В. Гербачевського (Gerbachevskiy, 2000), Торонтська алекситимічна шкала TAC-20 (Starostina, 2010), Шкала суб'єктивного благополуччя А. Пєруе-Баду та ін. в адаптації М. В. Соколової (Duhnovskiy, 2010), методика Еманс Р. та Маккалоу M (McCullough, 2002) для дослідження вдячності. Дослідження за обраними методиками, було проведено на вибірці підлітків та учнів ранньої юності від 13 до 18 років в учнівських колективах середньої та професійної шкіл. Вибірка налічувала 91 респондент. У дослідженні взяли участь хлопці та дівчата. Дівчат налічувалось 38 осіб, хлопців 57 осіб. Вибірка була поділена нами на умовні підкатегорії «підлітків» та представників «раннього юнацького віку», за віковим показником: підлітки - 13-15 років, представники раннього юнацького віку - 16-18 років.

Результати дослідження та їх обговорення. Характеристику вибірки та досліджені рівні суб'єктивного благополуччя учнів підліткового та раннього юнацького віку див. табл. 1.

Таблиця 1. Характеристика вибірки та досліджені рівні суб'єктивного благополуччя учнів підліткового та раннього юнацького віку (91 респондент)

\begin{tabular}{|c|c|c|c|c|}
\hline Вік & Повні роки & Кількість & $\begin{array}{c}\text { Високий рівень } \\
\text { суб'єктивного } \\
\text { благополуччя }\end{array}$ & $\begin{array}{c}\text { Низький рівень } \\
\text { суб'єктивного } \\
\text { благополуччя }\end{array}$ \\
\hline $\begin{array}{c}\text { Ранньо- } \\
\text { юнацький }\end{array}$ & $(16-18)$ & 45 & $56 \%$ & $44 \%$ \\
\hline Підлітки & $(13-15)$ & 46 & $42 \%$ & $58 \%$ \\
\hline
\end{tabular}

Як ми бачимо, присутні певні відмінності між рівнем суб’єктивного благополуччя у групах підлітків та представників раннього юнацького віку. В групі представників раннього юнацького віку відсоток осіб, які мають високий показник рівня суб'єктивного благополуччя виявився більшим ніж у групі підлітків. Такий показник ми пояснюємо тим, що підлітковий період складний етап, який включає в себе фізіологічні зміни, зміни в ціннісно-смисловій сфері життя людини, зміни в сфері контактів 3 дорослими, від яких надходять постійно зростаючі вимоги та необхідність прийняття складних рішень. Перебуваючи в напруженні через перелічені фактори, підлітки можуть відчувати зниження задоволеності життям, а відповідно і зниження суб'єктивного благополуччя.

В той час представники раннього юнацького віку, «зростаючи», отримують більше автономії, змоги вирішувати самостійно складні життєві обставини, самостійно задовольняти власні потреби, встановлювати стосунки, що призводить до зростання рівня задоволеності життям, а також збільшення рівня суб'єктивного благополуччя.

Для того аби визначити відмінності в переживанні суб'єктивного благополуччя ми провели процедуру поділу досліджуваних за результатами виконання методики ШСБ (шкали суб'єктивного благополуччя) (Duhnovskiy, 2010) на дві групи, тих, хто отримав низькі бали за шкалою суб'єктивного благополуччя, тобто оцінює власне суб'єктивне благополуччя вище норми (високий рівень суб'єктивного благополуччя) - (х $<5)$ в стеновому еквіваленті, та тих, хто отримав високі бали за шкалою суб'єктивного благополуччя, тобто оцінює власне суб'єктивне благополуччя нижче норми (низький рівень суб'єктивного благополуччя) - (х>5) в стеновому еквіваленті.

Нами був проведений розподіл на дві групи досліджуваних 3 високим рівнем суб'єктивного благополуччя та з низьким рівнем суб'єктивного благополуччя. Група з високим показником суб'єктивного благополуччя налічувала 51 особу, група 3 низьким рівнем суб'єктивного благополуччя налічувала 40 осіб. Зазначимо також, що співвідношення результатів з високими показниками суб'єктивного благополуччя та низькими показниками 
суб'єктивного благополуччя є близьким до 1,2 з перевищенням більш високих показників суб'єктивного благополуччя серед підлітків та представників раннього юнацького віку.

Для того аби проводити подальший аналіз нами був використаний непараметричний $U$ критерій Мана-Уітні, для розподілу вибірки на групи 3 низьким та високим рівнем суб’єктивного благополуччя; нами були виявлені наступні відмінності див. табл.2.

Таблиця 2. Значущі відмінності показників суб'єктивного благополуччя різних рівнев розвитку в учнів підліткового та раннього юнацького віку (91 респондент)

\begin{tabular}{|l|c|c|c|}
\hline $\begin{array}{c}\text { Середні показники за методиками для груп з високим (ВСБ) } \\
\text { та низьким (НСБ) суб'єктивним благополуччям }\end{array}$ & $\begin{array}{c}\text { ВСБ } \\
(\mathrm{n}=51)\end{array}$ & $\begin{array}{c}\text { НСБ } \\
(\mathrm{n}=40)\end{array}$ & $\begin{array}{c}\text { Рівень } \\
\text { значущості }\end{array}$ \\
\hline 1. Внутрішній мотив & $\mathbf{1 5 , 3}$ & 13,15 & $0,010^{* *}$ \\
\hline 2. Мотив самоповаги & $\mathbf{1 7 , 8}$ & 14,55 & $0,002^{* *}$ \\
\hline 3. Вольове зусилля & $\mathbf{1 4 , 1}$ & 12,50 & $0,028^{*}$ \\
\hline 4. Оцінка свого потенціалу & $\mathbf{1 7 , 0}$ & 13,38 & $0,000^{* *}$ \\
\hline 5. Очікуваний рівень результатів & $\mathbf{1 5 , 9}$ & 13,95 & $0,014^{*}$ \\
\hline 6. Труднощі ідентифікації почуттів & 17,8 & $\mathbf{2 1 , 7 5}$ & $0,008^{* *}$ \\
\hline 7. Труднощі з описом почуттів & 12,6 & $\mathbf{1 5 , 8 8}$ & $0,000^{* *}$ \\
\hline 8. Загальна алекситимія & 50,1 & $\mathbf{5 7 , 7 5}$ & $0,003^{* *}$ \\
\hline 9. Вдячність & $\mathbf{3 3 , 3}$ & 25,45 & $0,000^{* *}$ \\
\hline 10. Загальне самовладання & $\mathbf{4 8 , 7}$ & 42,66 & $0,000^{* *}$ \\
\hline 11. Особистісне. самовладання & $\mathbf{5 , 0}$ & 4,36 & $0,022^{*}$ \\
\hline 12. Екзистенціальне самовладання & $\mathbf{4 , 5}$ & 3,81 & $0,047^{*}$ \\
\hline
\end{tabular}

Рівень значущості $* 0 \leq 0,5 ; * * p \leq 0,01$

У Таблиці 2 ми можемо знайти значущі розбіжності (на рівні $\mathrm{p} \leq 0,01$ ) у ймовірному впливу на переживання суб'єктивного благополуччя між групами 3 високими та низькими показниками суб'єктивного благополуччя. Узагальненому респонденту з групи високого суб'єктивного на рівні значущості $\mathrm{p} \leq 0,01$ властиве завищення кількісних показників за такими критеріями: внутрішній мотив, мотив самоповаги, оцінка свого потенціалу, самооцінка, вдячність, особистісне самовладання, вольове зусилля, загальне самовладання, екзистенціальне самовладання. «Внутрішній мотив» представляє собою психічний процес, який відображає міру зацікавленості особистості самим процесом або змістом діяльності. «Мотив самоповаги» виражається в прагненні суб’єкта ставити перед собою все більш і більш складні цілі в однотиповій діяльності (працездатність). Показник «вольове зусилля» демонструє суб' єктивну оцінку особистістю ступеня вираженості вольового зусилля в процесі роботи (Gerbachevskiy, 2000). Показник загального самовладання демонструє здатність до керування своєю поведінкою, усвідомлення своїх потреб та їх задоволення, визначення та визнання внутрішніх протиріч та в одно час прагнення до гармонії. Особистісне самовладання розглядається як впевненість в своїх силах, здатність до витримки і холоднокровності в повсякденному житті; екзистенціальне самовладання - здатність до збереження гармонії з самим з собою в будь-яких обставинах (Zolotareva, 2018). Показник вдячності демонструє схильність особистості до довіри, доброзичливості (McCullough, Emmons \& Tsang, 2002.).

Виходячи 3 цього, ми можемо зауважити, що рівень суб'єктивного благополуччя має зв'язок з такими аспектами життя особистості, як здатність контролювати власні дії, йти до мети, керуючись лише внутрішньою мотивацією; об'єктивно до умов, які складаються, оцінювати власні сили та здібності, реалізовувати свої ідеї, перебуваючи в міцній взаємодії 3 іншими, встановлювати міцні емоційні зв'язки.

Частині представників нашої вибірки з низьким рівнем суб'єктивного благополуччя властиві кількісні показники за такими критеріями: значущість результатів, завищення оцінювання рівня досягнення результатів та загальна алекситимія. «Завищення оцінювання результатів» демонструє суб'єктивну оцінку рівня досягнутих результатів. «Значущість результатів» розглядається як надання особливого змісту діяльності (Gerbachevskiy, 2000), в негативному сенсі це можливо розглядати як відрив від реальності. 
Отже, на нашу думку, в даному випадку, зв’язок рівня суб'єктивного благополуччя особистості з їі аспектами життя може виражатися в виникненні труднощів у взаємодії з іншими, адже відсутність розуміння своїх емоцій та переживань інших може призводити до непорозумінь в міжособистісній взаємодії, яка в даному віковому періоді є провідною діяльністю особистості. Розбіжність між уявними та реальними досягненнями, при наявності завищених потреб та в умовах обмежених можливостей особистості, веде до неадекватної самооцінки, що стає причиною порушення поведінки, виникнення емоційного зриву, підвищення тривожності, зниження самоповаги, що в свою чергу впливатиме на якість життя та задоволеність від нього.

Тобто, попередньо ми можемо робити висновок, що різниця між високими та низькими показниками суб'єктивного благополуччя, може бути пов'язаною 3 низкою чинників між оцінкою показників, які спрямовані на внутрішні переживання (внутрішній мотив, мотив самоповаги, оцінка свого потенціалу, самооцінка, вдячність, загальне самовладання, вольове зусилля, особистісне самовладання, екзистенціальне самовладання) та показників, які спрямовані на зовнішню взаємодію значущість результатів, загальна алекситимія та їі складові: труднощі ідентифікації почуттів, труднощі з описом почуттів, оцінка рівня досягнення результатів.

Висновки. На основі аналізу теоретичних джерел ми визначили основні елементи, які досліджувались вітчизняними та зарубіжними представниками у проблематиці зв'язку між суб’єктивним благополуччям та показниками різних аспектів життя особистості в підлітковому та ранньому юнацькому віці: міжособистісна взаємодія, соціально - психологічна адаптація, належність референтній групі, впевненість в житті, самооцінка, мотивація досягнення успіхів в різних видах діяльності через прагнення до досягнення мети того ступеня складності, на який людина вважає себе здатною, здатність до саморозвитку. Особливо це стає актуальним при самоізоляції, в умовах обмежених ресурсів для налагодження соціальних контактів, міжособистісного спілкування, що $є$ провідною діяльністю для особистості в період підліткового та раннього юнацького віку На основі цього була сформована мета нашого дослідження, а саме: проаналізувати зв’язок рівня суб'єктивного благополуччя та аспектів життя особистості в період підліткового та раннього юнацького віку. У ході нашого дослідження нами були отримані наступні результати:

- Рівень суб'єктивного благополуччя має зв'язок з віковим показником. У нашому дослідженні представники ранньо-юнацького віку мають вищий рівень суб'єктивного благополуччя, порівняно 3 підлітками, що пояснюється нами умовами соціального життя підлітків, фізіологічними змінами, вимогами оточення по відношенню до них, що через суб'єктивне сприйняття веде до зниження рівня суб'єктивного благополуччя.

- Підліткам та частині представників раннього юнацького віку, які мають високий рівень суб'єктивного благополуччя, властиві досить виражені кількісні показники, за такими критеріями: внутрішній мотив, мотив самоповаги, оцінка свого потенціалу, самооцінка, вдячність, загальне самовладання, вольове зусилля, особистісне самовладання, екзистенціальне самовладання, що свідчить про їх здатність конгруентно до подій та ситуацій реагувати на зміни у середовищі, при тому реагувати відповідно вимогам, контролювати власні переживання та стосунки з іншими.

- Підліткам та представникам раннього юнацького віку, які мають низький рівень суб'єктивного благополуччя властиві високі кількісні показники за такими критеріями: значущість результатів, загальна алекситимія (за факторами - труднощі ідентифікації почуттів, труднощі з описом почуттів) та завищення за показником оцінка рівня досягнення результатів. Це свідчить про труднощі в афективній сфері, не розуміння емоцій та неможливість їх ідентифікації, відрив від реального оцінювання власних досягнень, що може стати причиною зниження задоволеності життям та ускладнення процесу взаємодії з іншими.

На перспективу подальшої розробки даної проблематики, ми вважаємо за доцільне розробити тренінгову програму для психологічного впливу на підлітків та представників раннього юнацького віку, яка включатиме у себе роботу з афективною та когнітивною сферами особистості, a саме: тренінг емоційного інтелекту, навичок ефективної комунікації, розвиток навичок саморефлексії та майнфулнес (усвідомлення). На сьогоднішній день, при зміні соціальних умов, в зв'язку з розповсюдженням Covid - 19, актуальною стає тема дослідження зв'язку суб'єктивного благополуччя особистості з їі аспектами життя, які проявляються в порушенні психічних процесів особистості (працездатності, мотивації навчання, інтелектуальних здібностей, адекватної емоційної оцінки особистісних домагань та їх результатів та інше). 


\section{REFERENCES}

1. Bocharova E. E. (2012). Psihologiya sub'ektivnogo blagopoluchiya molodezhi [Psychology of youth subjective well-being]. Saratov: SGU (in Russ.).

2. Gasper, D. (2004). 'Human Well-being: Concepts and Conceptualizations', WIDER Discussion Paper 2004/06 (Helsinki: UNU-WIDER).

3. Gorbachevskiy, V. K., Balin, V. D. \& Gayda, V. K. (2000). Praktikum po obschey, eksperimentalnoy $i$ prikladnoy psihologii [Workshop on General, Experimental and Applied Psychology] (A. A. Kryilova, S A. Manicheva Ed.) SPb: Piter (in Russ.).

4. Gorbal I. S., (2016). Social'no - psyhologighni cynnyky subiektyvnoho blahopoluchchia [Social and psychological factors of subjective well-being of pensioners] Kandydats'ka dysertatsiia [Candidate's dissertation]. L'viv: LNU (in Ukr.).

5. Diener, E., Oishi, S. \& Lucas, R. E. Personality (2003). Culture, and subjective well-being: Emotional and cognitive evaluations of life. Annual Review of Psychology 54:403-425.

6. Duhnovskiy, C. (2010). Diagnostika mezhlichnostnyih otnosheniy. [Diagnostics of interpersonal relationships]. $\mathrm{SPb} .:$ Rech. (in Russ.).

7. Zolotareva, A.A. (2018). Test samoobladaniya: psihometricheskie harakteristiki i perspektivyi primeneniya.[ Self-control test: psychometric characteristics and application prospects] Psihologicheskiy zhurnal, tom 39, 1, 103-114. DOI:10.7868/S020595921701010X

8. Kulikov L. V. (2000). Zdorov'e i sub'ektivnoe blagopoluchie lichnosti [Health and subjective well-being of the individual]. (G. S. Nikiforov, Ed). St. Petersburg: St. Petersburg University Publ. (in Russ.).

9. McCullough, M., Emmons, R.A., \&amp; Tsang, J. (2002). The grateful disposition: a conceptual and empirical topography. Journal of personality and social psychology, 82 1, 112-27

10. Puchkova G. L. (2003). Sub'ektivnoe blagopoluchie kak faktor samoaktualizatsii lichnosti [Subjective well-being as a factor in the self-actualization of personality]. Kandidatskaya dissertatsiya [Candidate's dissertation]. Habarovsk: DIPiP (in Russ.).

11. Romaniuk L. V. (2014). Psykholohiia stanovlennia tsinnostei osobystosti [Psychology of personality values formation]. Doktors'ka dysertatsiia [Doctoral dissertation]. Kyiv: KNU (in Ukr.).

12. Salihova N. R. (2015). Psihologicheskie problemyi smyisla zhizni i akme: Elektronnyiy sbornik materialov $X X$ simpoziuma [Psychological problems of meaning of life and acme: Electronic collection of materials of the XX symposium] (G.A. Vayzer, N.V. Kiselnikovoy, T.A. Popovoy, Ed.). Moskva: FGBNU "Psihologicheskiy institut RAO" (in Russ.).

13. Santrock, J.W. (2006). Life- span development: Perkembangan masa hidup, Jilid 2. Penerbit Erlangga.

14. Shamionov R. M. (2004). Sub'ektivnoe blagopoluchie lichnosti [Subjective well-being of the individual]. Saratov: Nauchnaya kniga (in Russ.).

15. Starostina, E., Teylor, G., Kvilti, L., Bobrov, A., Moshnyaga, E., Puzyireva, N., Bobrova, M., Ivashkina, M., Krivchikova, M. (2010). Torontskaya shkala aleksitmii (20 punktov): validizatsiya russkoyazyichkoy versii na vyiborke terapevticheskih bolnyih. [Toronto alexithmia scale (20 points): validation of the Russian-language version in a sample of therapeutic patients.]. Sotsialnaya i klinicheskaya psihiatriya. 20, 4. 31-38. 